Muñoz Albaladejo, J. (2020): Infancia, naturaleza y pesimismo político en la obra de George Orwell: un análisis pormenorizado del concepto Golden Country. Cultura, Lenguaje y Representación, Vol. XXIII, 135-150

ISSN $1697-7750 \cdot$ e-ISSN $2340-4981$

DOI: http://dx.doi.org/10.6035/clr.2020.23.9

\title{
Infancia, naturaleza y pesimismo político en la obra de George Orwell: un análisis pormenorizado del concepto de Golden Country
}

Childhood, nature and political pessimism in the work of George Orwell: a detailed analysis of the Golden Country

JosÉ MuÑOZ ALBALADEJO

INSTITUTO DE CIENCIAS DEL PATRIMONIO (INCIPIT)

CONSEJO SUPERIOR DE INVESTIGACIONES CIENTÍFICAS (CSIC)

Artículo recibido el / Article received: 2018-10-23

Artículo aceptado el / Article accepted: 2020-03-26

RESUMEN: El presente artículo se centra en analizar los elementos sobre los que Orwell estructura el concepto de Golden Country, término que emplea únicamente en su última novela, Mil novecientos ochenta y cuatro, pero que encierra tras de sí todo el pensamiento político del autor. Se trata de un concepto que puede ya anticiparse en Subir a por aire, pero que tanto sus vivencias personales, en las que la Guerra Civil Española juega un papel esencial, como el auge de los totalitarismos acaban moldeando hasta su incursión definitiva en su obra cumbre, Mil novecientos ochenta y cuatro. Partiendo de la definición del Golden Country, y después de preguntarnos por el lugar que podría ocupar dentro de la historia de la literatura utópica, este artículo recorre la obra de Orwell con el fin de analizar los principales elementos que se encuentran detrás de dicho concepto: infancia, naturaleza, desencanto y pesimismo político. Al final, se verá que lo que el Golden Country encierra no son solo los anhelos y deseos de su autor, sino también su impotencia ante el exceso de mecanización y sus temores ante un futuro que se avecina incierto y, sobre todo, desolador.

Palabras clave: George Orwell, política, pesimismo, infancia, naturaleza, totalitarismo, Golden Country, nostalgia.

ABSTRACT: This article focuses on the analysis of the elements which structures the Orwellian concept of Golden Country. This concept is only mentioned in his last novel, Nineteen Eighty-Four, but it contains all the political thought of the author. The origin of the term can be found in the references to childhood and nature that Orwell makes in his novel Coming up for air, and his personal experiences - specially, the Spanish Civil War - the arrival of the war and the rise of totalitarianism end up shaping it until its final incursion in his masterpiece, Nineteen Eighty-Four. Starting from the definition of the Golden Country, this article goes through Orwell's work in order to analyze the main elements that are behind that concept: childhood, nature, disenchantment and 
political pessimism. In the end, we can see that what is contained in the Golden Country is not just the wishes and desires of its author, but also his impotence in the face of excessive mechanization and his fears about a future that is uncertain and devastating.

Key words: George Orwell, politics, pessimism, childhood, nature, totalitarianism, Golden Country, nostalgia

\section{EL GOLDEN COUNTRY: UNA DEFINICIÓN}

De pronto, se vio de pie sobre el césped en una tarde de verano en que los rayos oblicuos del sol doraban la corta hierba. El paisaje que se le aparecía ahora se le aparecía con tanta frecuencia en sueños que nunca estaba completamente seguro de si lo había visto alguna vez en la vida real. Cuando estaba despierto, lo llamaba el Golden Country.

(Orwell, 2002: 38-39)

Así nos presenta George Orwell el Golden Country: como un lugar idílico de cuya existencia no se puede estar seguro. Tan solo se menciona cuatro veces en su última novela, Mil novecientos ochenta y cuatro, pero los elementos que lo componen están ya presentes tanto en sus obras anteriores como en su propia vida. El Golden Country es el viaje a la infancia y el deseo de recuperar el recuerdo de una Inglaterra de comienzos de siglo que no podrá volver a ser tal como era, el recuerdo de la paz que había cuando la guerra no se dejaba entrever. En él se encierran los deseos más profundos de Orwell, pero también todos sus temores.

Nos encontramos ante un concepto que, si bien ha sido mencionado ya en diversas investigaciones anteriores (e.g. Woodcock, 1966; Bloom, 2004; Stephens, 2004; Shin, 2017), no ha sido profundamente analizado, a excepción tal vez del artículo de Shin (2017), que analiza el Golden Country como un espacio indefinido ubicado en la disyunción que se produce entre el nostos (retorno) y el algia (dolor), pero alejado, como también en las páginas que siguen se defenderá parcialmente, de una especie de nostalgia restauradora íntimamente vinculada con la romántica idealización de la infancia ${ }^{1}$. Lo que el presente artículo pretende aportar al conocimiento del Golden Country es la idea de que los elementos que sirven para su configuración están ya presentes tanto en la vida como en la obra previa de su autor - especialmente en la novela Subir a por aire-, de tal manera que podríamos llegar a decir que nos encontramos ante un concepto que es, en sí mismo, una especie de corolario del pesimismo político orwelliano. No es que el Golden Country sea el destino teleológico hacia el que Orwell haya orientado toda su obra, pero sí que supone una especie de síntesis final que viene a englobar y resumir el desarrollo progresivo de aquellas ideas y elementos que han marcado todo su pensamiento y toda su obra narrativa. Así, nuestro viaje comenzará con la pregunta acerca de la ubicación de este elemento dentro de la literatura utópica, para posteriormente hacer un recorrido por aquellas características que van, poco a poco, configurando lo que luego desembocará en la creación de este espacio imaginado: infancia, naturaleza, el presagio de la guerra, su vivencia de esta — por partida doble, además; una como actor, la Guerra Civil Española; otra como espectador, la Segunda Guerra Mundial—, el auge de los totalitarismos y, finalmente, el desencanto y consiguiente pesimismo políticos.

\footnotetext{
${ }^{1}$ La nostalgia, como luego mencionaremos, no se orienta tanto a la infancia perdida, sino a todos los valores que Orwell asocia a ella.
} 
Todo eso es lo que encierra el concepto de Golden Country. Un concepto que aparece por primera vez en la novela Mil novecientos ochenta y cuatro justo después de que Winston Smith, su protagonista, recuerde a su madre y a su hermana. Winston se sueña a sí mismo en un campo rodeado de árboles. Una joven se acerca a él a medida que se va desprendiendo de sus ropas. De repente, Winston se despierta con la palabra «Shakespeare» en su boca: el recuerdo inconsciente de los tiempos antiguos. Su mundo es todo lo contrario al lugar con el que acaba de soñar. No hay naturaleza, solo imponentes construcciones que parecen aniquilarlo todo. Ni siquiera existe la libertad de poder desprenderse de la ropa, o de correr a abrazar a la persona a la que amas. Tampoco existe la libertad de amar. El mundo real es lo opuesto al Golden Country. Éste no es más que una vía para «escapar de la estridencia de su entorno inmediato» (Rai, 1990: 85), pero es inexistente, un lugar situado fuera del tiempo y del espacio. En él se aúnan tanto el deseo de volver a un pasado idílico como la esperanza de construir un futuro que nada tenga que ver con un presente opresor. En la novela, más adelante, cuando Julia conduce a Winston a un paraje natural, éste susurra: «Es el Golden Country... casi» (Orwell, 2002: 131). El «casi» es importante: indica la imposibilidad de su existencia real. Porque, al final, el Golden Country no es más que un amasijo de recuerdos y deseos entremezclados que no responden tanto a las añoranzas de Winston Smith como a las aspiraciones de Orwell.

Sin embargo, aunque este concepto solo aparezca mencionado como tal en Mil novecientos ochenta y cuatro, los elementos que conforman su estructura pueden encontrarse ya en la obra anterior de su autor. La mención a Subir a por aire, escrita en 1939, es esencial en este sentido ${ }^{2}$ : en ella, el protagonista, George Bowling, decide regresar a su Lower Binfield natal con el fin de recuperar parte del recuerdo feliz de infancia que ahora, en su monótona vida de agente de seguros y en un país cuya entrada en la guerra se presume inevitable, es incapaz de encontrar. De nuevo Orwell recurre a los mismos tópicos: naturaleza, infancia, paz, felicidad. Libertad. Pero recurre a ellos tan solo para advertirnos de lo que ya hemos perdido.

La pasión de Orwell por la vida rural de su país, la denominada Old England, ha sido remarcada constantemente por sus biógrafos, y la construcción del Golden Country como una vía de escape de la realidad moderna hacia un pasado idílico está influenciada por ese anhelo de regresar a los tiempos donde la imagen de la Vieja Inglaterra estaba todavía latente en el imaginario colectivo de sus contemporáneos. Suele relacionarse el recurso al Golden Country con la nostalgia hacia lo rural del propio Orwell, aunque en realidad este concepto encierra mucho más que ese sentimiento (Shin, 2017), como veremos después. Eso no quita que, probablemente, las imágenes que Winston Smith sueña sean también las imágenes que el propio Orwell tenía en la cabeza, pues es de suponer que alguien como él, formado en Eton y procedente de una familia inglesa de clase media-alta, no sea ajeno a toda esa tradición pictórica liderada por artistas como Thomas Gainsborough, George Lambert o John Constable, que se encargaban de representar continuamente el british landscape y la rural England como un espacio de ensueño (Barrell, 1992).

Las referencias a la naturaleza son constantes, y en múltiples ocasiones el propio Orwell intentó alejarse de la modernidad que él tanto detestaba instalándose en pequeñas casas de campo. Lo hizo cuando se marchó a Marruecos, etapa en la que escribió Subir a por aire, y lo hizo también al final de su vida, trasladando su residencia a la lejana isla escocesa de Jura, donde terminó de redactar Mil novecientos ochenta y cuatro. En su ensayo de 1946 titulado Algunas reflexiones en torno al sapo común, Orwell tachará de

\footnotetext{
${ }^{2}$ De hecho, Woodcock (1966: 217) deja caer que algunos de los detalles descritos en el Golden Country de Mil novecientos ochenta y cuatro beben directamente de lo ya narrado en Subir a por aire.
} 
«manifiestamente falsa» (Orwell 2013: 749) la idea de que para amar el campo hay que vivir en la gran ciudad, tan extendida en aquellos días. Unos años antes, en el texto titulado En el vientre de la ballena, Orwell hará múltiples referencias a la poesía naturalista inglesa, por lo que podemos suponer que también esas imágenes idílicas que los poetas de su tierra dedicaron a la vida alejada de las grandes ciudades influyeron en su modo de concebir y pensar el mundo. A partir de todas estas consideraciones, no parece imprudente afirmar que la imagen que, en el fondo, trata de representar el Golden Country, bebe directamente de las representaciones paisajísticas propias de la literatura bucólica (Bloom, 2004), las mismas sobre la que escribían los poetas románticos ingleses (Marinelli, 2018). Pero esas imágenes pronto fueron desapareciendo, y esa desaparición es lo que Orwell narra en la novela Subir a por aire a través de los pensamientos de George Bowling, un hombre de mediana edad que está atrapado entre dos formas de vida distintas, la de la Inglaterra tradicional en la que creció y la de la Inglaterra moderna en la que le ha tocado vivir y que escapa a su comprensión.

Los elementos esenciales del Golden Country son el recurso a la infancia y la alusión a la naturaleza, pero en la construcción de ese espacio ideal y arcádico participan también muchos otros hechos que fueron, poco a poco, definiendo la ideología y el carácter de George Orwell desde antes incluso de apodarse a sí mismo George Orwell, desde los tiempos en que tan solo era Eric Blair. La naturaleza presente en el landscape inglés y en las imágenes de la vida rural del país juega su papel en la construcción del concepto, del mismo modo que también lo hace la infancia de su autor. Esa infancia, cargada de recuerdos previos al estallido de la Gran Guerra, no solo es añorada por Orwell por ser parte de una época feliz en la que los desastres bélicos todavía no habían tenido lugar, sino también porque se trataba de una época repleta de valores que el mundo moderno ha ido enterrando poco a poco, y la pérdida de esos valores es algo que el propio Orwell no puede nunca terminar de aceptar, especialmente la pérdida de los espacios privados y de libertad individual. En el fondo, el Golden Country puede ser entendido como ese lugar que representa, en el imaginario de Orwell, el espacio en el que la libertad individual y los valores del pasado todavía permanecen vivos, intactos. La nostalgia no se dirige, por tanto, a su infancia, sino a los valores que hemos perdido y que son ya irrecuperables.

\section{UNA BREVE APROXIMACIÓN A LOS CONCEPTOS DE «PARAÍSO»Y «UTOPÍA». ¿FORMA EL GOLDEN COUNTRY PARTE DE ELLOS?}

El concepto de utopía significa, literalmente, no-lugar; su nombre se le debe a Tomás Moro, que lo mencionó por primera vez en su obra Utopía, publicada en el siglo XVI, para hacer referencia a un sitio imaginario que aspiraba a hacerse realidad, un lugar inexistente pero idílico. Desde Platón hasta la época actual, el hombre ha imaginado ciudades ideales en donde poder sentirse totalmente realizado. En el caso de Orwell, podríamos decir que su Golden Country es precisamente uno de esos lugares imaginarios en los que el ser humano es capaz de alcanzar dicho objetivo; pero, como en toda utopía, su invención no implica la posibilidad real de su construcción, sino que actúa tan solo como respuesta a la sociedad totalizadora del mundo descrito en Mil novecientos ochenta y cuatro, que a su vez funciona como crítica a la sociedad de la época. Thomas Cushman (2004), de hecho, ya nos advierte de que, más que ante una simple novela, estamos ante un texto de análisis sociológico del totalitarismo que todavía hoy nos es útil para interpretar la realidad moderna. 
La literatura utópica ${ }^{3}$ está formada por textos proyectivos en los que el autor traza un plan cuya realización podría servir para mejorar en cualquier aspecto la realidad en la que vive, pero sin la intención siquiera de ejecutarlo: por definición, la utopía es inalcanzable. Pero, por encima de todo, un texto utópico se caracteriza por su función crítica. Las utopías nacen de la preocupación por los problemas sociales que les son coetáneos; los utopistas reflejan esos problemas tratando de captar la angustia de toda una época e imaginando un lugar en el que esos conflictos por fin han sido solucionados. El utopista postula una nueva realidad como alternativa a la realidad en la que se encuentra. Esto genera una tensión entre lo real y lo imaginario. Por eso utopía e Historia están directamente relacionadas: porque las utopías se crean como crítica a un momento concreto de la Historia y como alternativa a dicho momento, y, conforme la Historia avanza, las utopías van modificándose. El discurso utópico habla de acuerdo a las condiciones de cada época y, generalmente, en contra de dichas condiciones. Raymond Trousson deja esta idea muy clara cuando señala que la utopía «nace de un sentimiento de rebelión ante un estado histórico considerado insatisfactorio» (1995: 41). El pensamiento utópico nos abre la puerta de la posibilidad, pero, a la vez, se niega a facilitarnos los instrumentos necesarios para la construcción de esas posibilidades.

Teniendo esto en cuenta, no podemos afirmar de forma contundente que el Golden Country sea una utopía, aunque sea común a ella en muchos aspectos. Su significado, quizá, se acerca más al del concepto de Paraíso o Jardín del Edén: aquel lugar idílico y primigenio anclado en la naturaleza y al que ya no podemos regresar. Tomado en su sentido bíblico, el concepto de Paraíso nos muestra una imagen del origen de la vida como un momento feliz, similar a la Edad de Oro que ya describiese el poeta griego Hesíodo. Hablamos de lugares felices, sin castigos, sin leyes escritas, sin crímenes, en los que los seres humanos eran completamente libres. La única condición que se le impone al ser humano es la de no transgredir las leyes de la Naturaleza. Pero cuando el Paraíso desaparece, éste se convierte en pasado inalcanzable al que lloraremos y cuya vuelta reclamaremos en vano. El momento feliz del Paraíso se sitúa en un pasado muy lejano al que nunca podremos regresar. En ese sentido, el Golden Country podría situarse a medio camino entre el Paraíso y la Utopía: es un lugar pasado al que no se puede volver, pero también una esperanza de futuro que es irrealizable y que se contrapone a la realidad presente. A su vez, además, es también un lugar imaginado que, en realidad, se inserta, como ya se ha mencionado antes, dentro de una tradición literaria propia de la novela pastoril $^{4}$ (Fowler, 1995; Bloom, 2004), un género que recuperó el recurso a la Arcadia como mundo feliz y pacífico habitado por pastores, pero situado fuera de todo tiempo y más allá de la realidad. Una atemporalidad inicial que más tarde quedaría materializada en la vida en el campo de los pastores ingleses y personificada precisamente en ellos, a través de los textos escritos por los poetas románticos de mediados del siglo XVIII. De esta tradición es deudor el Golden Country imaginado por Orwell.

\section{LOS ELEMENTOS ESENCIALES DEL GOLDEN COUNTRY: INFANCIA Y NATURALEZA}

En su Infancia en Berlín hacia 1900, Walter Benjamin (1982) señala en un momento dado que soñar con cómo se aprendió a andar no sirve de nada, pues una vez que ya lo sabes hacer, no volverás jamás a aprenderlo. A lo largo de toda esta obra, la mezcla de sentimientos que se desprenden de las palabras de Benjamin es constante. Se

\footnotetext{
${ }^{3}$ Para conocer más sobre la literatura utópica en general, y sobre el avance de esta disciplina en el siglo XX, puede consultarse el texto de Manuel y Manuel (1984).

${ }^{4}$ Sobre este género, ver Marinelli, 2018.
} 
anhela la infancia, se quiere recuperar, pero se sabe perdida; está ahí y su recuerdo nos puede hacer sonreír, pero ya se ha ido. En el caso de Orwell ocurre lo mismo. Recordemos que el Golden Country aparece mencionado por primera vez justo en el momento en el que Winston sueña con su madre y su hermana. En esas referencias hay, de hecho, algo de la propia vida de su autor: siendo todavía un niño, en 1912, su familia se traslada a una pequeña casa situada en una aldea, junto al río. Esto provocó un completo cambio en su modo de pensar, y ese «escenario mágico» rodeado de naturaleza se convirtió tanto en el Lower Binfield que George Bowling recuerda en Subir a por aire como en el paisaje idealizado que Winston Smith imagina en Mil novecientos ochenta y cuatro (Bowker, 2003: 41).

Sin embargo, al contrario de lo que se pueda llegar a pensar, Orwell en ningún momento hace una apología de su infancia. George Bowling, el protagonista de Subir a por aire - una especie de alter ego del propio Orwell—, lo tiene muy claro: «no idealizo mi infancia y, a diferencia de mucha gente, no tengo ningún deseo de volver a ser niño» (Orwell, 1981: 78). No sentir una absoluta nostalgia por la infancia que ya no volverá, no querer regresar a ella, no significa, sin embargo, que no se tenga derecho a añorarla. Lo que Orwell añoraba era aquella Inglaterra en donde, en cierto sentido, la vida parecía más fácil, aunque hubiese hambre y hubiese enfermedades; añoraba la Inglaterra previa a la industrialización, la Inglaterra en la que un tipo como Bowling podía ir a pescar a un pequeño lago escondido a las afueras de la ciudad y disfrutar de una paz que, en todo caso, podía encontrarse casi en cualquier rincón. Ahora, sin embargo, ese lago que fascinó a Bowling ya no existe. Igual que el personaje de Subir a por aire, Orwell añora la época de antes de la guerra, pero lo hace no tanto porque entonces esta aún no había tenido lugar, sino porque aquella era una época cuyos habitantes «no veían el futuro como motivo de temor» (Orwell, 1981: 108). Es el propio Orwell el que habla a través de la boca de Bowling; Gordon Bowker (2003), de hecho, tiene muy claro que tanto las miradas al pasado de George Bowling como los fugaces recuerdos que a Winston Smith se le revelan en sueños no son más que una visión de su propia infancia como un «retiro feliz» al que Orwell acudió en su madurez, un lugar en el que recordar con nostalgia esos pequeños destellos de esperanza que ahora, ya adulto, le parecen inconcebibles (Bowker, 2003: 17).

Su presunta idealización de la infancia se debe, en gran medida, a que ella es el reflejo de un cambio de mundo. La infancia de Orwell no tiene nada que ver con la infancia de los niños que nacen treinta años después. Donde él vio campo, aquellos solo ven ciudades; donde él respiró aire, aquellos solo respiran humo. El cambio ha sido tan brusco y tan repentino que su asimilación todavía sigue inquietando al Orwell adulto, como si éste nunca terminase de aceptarlo. Y lo peor no es tanto ese cambio sino, como dice el propio Bowling, la mirada hacia el futuro que tales cambios producen. En $\mathrm{Mil}$ novecientos ochenta y cuatro, Winston Smith nunca logra recordar cómo es el Londres de su infancia. Se pregunta si aquella ciudad decrépita en la que ahora habita ha sido siempre así, igual de decrépita, igual de triste. «Pero era inútil, no podía recordar: nada le quedaba de su infancia excepto una serie de cuadros brillantemente iluminados y sin fondo, que en su mayoría le resultaban ininteligibles» (Orwell, 2002: 11). Imágenes que se repiten como si de un déjà $v u$ (Shin, 2017) se tratase: sin la certeza de que alguna vez ocurrieron. Unas páginas más adelante, justo antes de mencionar por primera vez el Golden Country, Winston sueña, ya lo hemos dicho, con su madre y su hermana. Aunque las imágenes son confusas, el recuerdo de ellas está enmarcado en una época en la que, a diferencia de la que le rodea, era posible el amor, la vida privada y la amistad, algo que en aquel momento había ya desaparecido. Esos conceptos solo son posibles en el recuerdo de la infancia. Y lo que él llega a sentir alguna vez por Julia $-\mathrm{y}$ no, en cambio, por su 
mujer- es lo más parecido a esas extrañas sensaciones que solo eran accesibles gracias a los escasos recuerdos que todavía parecía mantener.

Sin embargo, algunos de sus escritos parecen indicarnos que la infancia de Orwell no fue, en realidad, sinónimo de felicidad, como lo atestigua, entre otras cosas, que se basase en sus días en la escuela de St. Cyprian para configurar el reinado del terror que podemos leer en Mil novecientos ochenta y cuatro, y a pesar de que todo eso no parezca casar con esa añoranza del pasado que se refleja en Subir a por aire. Aun así, tampoco es descabellado pensar que la infancia de Orwell no fue tan mala como algunos de sus escritos más personales parecen indicarnos. Avril Dunn, hermana de Orwell, es muy tajante al respecto: «Se ha dicho que Eric tuvo una infancia triste. No creo que esto fuera cierto en lo más mínimo, aunque él daba esta impresión cuando ya era mayor» (Coppard y Crick, 1989: 35). Y es evidente que si su infancia hubiese sido realmente tan triste como podría parecer, Bowling no recordaría sus días en Lower Binfield ni Winston Smith soñaría con un Golden Country que está inspirado de una forma clara en los lugares en los que el pequeño Eric Blair veraneó siendo todavía un niño. En Subir a por aire, Bowling lo explica con las siguientes palabras:

Las casas no tenían cuarto de baño, y en las mañanas de invierno, para lavarse, había que romper el hielo de la palangana. Cuando hacía calor, las calles pequeñas olían como el demonio, y el cementerio estaba en el mismísimo centro del pueblo, de modo que no pasaba un día sin que uno recordase cómo había de acabar. Y sin embargo, ¿qué era lo que tenía la gente en aquellos tiempos? Una sensación de seguridad, aun cuando no estuviesen seguros. Era, más bien, una sensación de continuidad.

(Orwell, 1981: 109)

Se trata, por tanto, de una sensación de seguridad que se fundamenta en la continuidad prometida por las sociedades occidentales, por una cierta estabilidad que no parece correr peligro ni tiene por qué temer a nada, porque eso es lo que el nuevo mundo le promete a uno: que no habrá de temer por su futuro. Pero esa promesa quedará, al final, truncada por la guerra, y con ella llegará también la más absoluta modernidad.

El otro gran elemento que conforma el Golden Country es la referencia a la naturaleza, directamente relacionado con el anterior. En Subir a por aire, la nostalgia de Bowling se dirige sobre todo a un tiempo y a un espacio que ya se han perdido para siempre: el tiempo de su infancia y el espacio de Lower Binfield. Pero ambas cosas no están separadas: en realidad, lo que se añora no son ese tiempo y ese espacio, sino ese tiempo en ese espacio. Se añora la imagen de la naturaleza que rodeaba a su pueblo, que Orwell vinculaba con un lugar feliz. Hay una escena en Subir a por aire en la que el personaje de Bowling, mientras conduce su coche hacia su propio pasado - Lower Binfield-, decide pararse en un lugar al lado de la carretera repleto de césped y flores. En ese momento, Bowling, un hombre de cuarenta y cinco años, con dentadura postiza, casado con una mujer de la que no está enamorado, con unos hijos que le son indiferentes y con un trabajo que odia, se siente feliz. «Me sentía feliz» (Orwell, 1981: 165), afirma, y la palabra aparece en cursiva en el original ${ }^{5}$, como dándonos a entender que todo lo que aquella palabra encerraba en ese preciso instante era, de hecho, inefable.

No es solo esa visión del mundo de antes de la guerra la que es idílica; lo es también la sensación de que aquel era un mundo en el que uno podía respirar aire puro. La expresión «subir a por aire» significa precisamente eso: viajar al pasado a tomar un poco de ese aire limpio y fresco que hace ya tiempo que nos es imposible encontrar en la gran ciudad. El refugio del Golden Country en el Londres de Mil novecientos ochenta y

\footnotetext{
${ }^{5}$ En cursiva en la traducción al español utilizada para este artículo; en mayúsculas en la versión original inglesa.
} 
cuatro sirve, por tanto, para subir a tomar un poco de aire: frente al humo de la ciudad, el aire de ese lugar inexistente se muestra en la memoria de Winston como si de la última bocanada de esperanza se tratase. La hierba verde en una tarde de verano, porque siempre es verano. Igual que en Subir a por aire: «Si cierro los ojos y pienso en Lower Binfield como era antes de que yo tuviese, pongamos, ocho años, siempre lo recuerdo en verano» (Orwell, 1981: 43). Siempre verano y siempre en el campo, rodeado de verde. De hecho, no son pocos los textos que revelan la pasión de Orwell por el campo. «Era un devoto campesino y un naturalista» (Lewis, 1984: 72), dirá de él Peter Lewis, mientras que Gordon Bowker añadirá lo siguiente:

En sus recuerdos, aquellos son días con una constante luz solar, los ríos y los estanques siempre llenos de peces. Durante su vida, [Orwell] siempre trataba de recrear esta experiencia, permaneciendo tan cerca de la naturaleza como pudiese, escapándose cuando era posible a pescar o a hacer excursiones por el campo.

(Bowker, 2003: 25)

Pero Orwell no construye el Golden Country tan solo a través de su anhelo por la infancia ni de su deseo de naturaleza. Estos conceptos van siempre entrelazados con toda una serie de circunstancias personales, políticas, ideológicas, que en la mayoría de los casos escapan a su control, y que le hacen caer en una especie de pesimismo que terminará de consolidarse y se convertirá en elemento clave de su pensamiento a partir, especialmente, de sus vivencias durante la Guerra Civil Española. El constante humor negro que muestran sus escritos y la vitalidad con la que parece afrontar muchos de los hechos que suceden a su alrededor son, podríamos decir, actos encaminados a luchar contra ese pesimismo político, casi existencial, que dominará prácticamente todas las esferas de su vida. Es un pesimismo causado por una serie de acontecimientos dispersos pero relacionados entre sí. El desencanto político debido al auge de los totalitarismos, el desengaño ideológico, el aumento del control social, la sustitución de la Inglaterra de su infancia por aquella otra que está tan orientada a la industria y la mecanización, la experiencia de la guerra. Todo eso conduce a la figura de Orwell a la creación de ese espacio imaginario que es el Golden Country.

\section{SUBIR A POR AIRE Y EL PRESAGIO DE LA GUERRA}

Considerada por alguno de sus biógrafos como su mejor y más personal novela (Crick, 1982), Subir a por aire, a priori, no parece tener un argumento muy complejo: un tipo, George Bowling, que se describe a sí mismo como feo, gordo y de clase media, aburrido de su mujer y sus hijos, decide escapar durante una semana a su pueblo natal, Lower Binfield, tras haber ganado una pequeña cantidad de dinero en las apuestas. Cuando regresa, sin embargo, todo ha cambiado. Apenas reconoce las calles, el pueblo ha incrementado su tamaño notablemente y la disposición de las casas se asemeja en exceso a las de cualquier típico barrio de ciudad. Pero aún le queda una última esperanza: el estanque en el que una vez vio unas carpas enormes y al que deseaba regresar para practicar su gran afición olvidada, la pesca. Pero el estanque ya no existe. Peor todavía: ahora se utiliza como un vertedero de basuras. «Como es natural, en alguna parte hemos de tirar las latas y todas estas cosas» (Orwell, 1981: 218), dice uno de los nuevos habitantes, a la vez que presume, hipócritamente, de que aquella zona está rodeada de una verde naturaleza a la que denominan «el Valle de los Duendes», porque no quieren echar abajo un paraje natural como aquel. «La naturaleza, ya sabe usted» (Orwell, 1981: 218).

\footnotetext{
${ }^{6}$ Todas las citas procedentes de textos en otros idiomas han sido directamente traducidas por el autor.
} 
Impotente, George Bowling decide regresar a su casa, no sin antes mencionar unas palabras que no tienen desperdicio alguno:

El Valle de los Duendes. Y habían llenado mi estanque de basura. La madre que les parió. Digan ustedes lo que quieran, llámenlo tonto, infantil, lo que quieran, pero ¿no les entran ganas de vomitar a veces de ver lo que están haciendo con Inglaterra, con sus estanques de cemento y sus enanitos de yeso, con sus duendes y sus basuras en los lugares donde antes estaban los hayales? ¿Que esto es sentimentalismo, dicen? ¿Que es antisocial? ¿Que no debería preferir los árboles a los hombres? Pues depende de qué árboles y qué hombres.

(Orwell, 1981: 218)

Las palabras de Bowling son, en realidad, las palabras de Orwell. Tanto Peter Lewis (1984) como Christine Berberich (2001) coinciden en señalar que, de hecho, Subir a por aire es un reflejo de las memorias de Orwell sobre su propia infancia. Otro de sus biógrafos, Gordon Bowker (2003), tampoco duda al afirmar que Orwell se centró en su propia infancia a la hora de escribir esta novela, mientras que Mitzi Brunsdale señala que George Bowling, en realidad, recibe los «recuerdos felices de los días de pesca de la infancia de George Orwell, sus mágicas horas con otros chicos mayores que finalmente dejaron que les acompañase» (2000: 109). En este sentido, Berberich (2001) también apunta que no es una mera casualidad que el protagonista de la novela tenga el mismo nombre que Orwell decidió usar como apodo para firmar sus obras, y que la nostalgia de Bowling por la Inglaterra de su infancia representa en el fondo la nostalgia que el mismo Orwell siente por los días de su niñez, o al menos por lo que ella representaba a nivel simbólico. En cierto momento, Bowling le dirá al lector que no está del todo seguro de si aquel otro mundo se ha ido ya para siempre, pero que, en cualquier caso, lo que sí es seguro es que aquel «era un mundo agradable para vivir», para después añadir que "yo pertenezco a ese mundo. Y ustedes también» (Orwell 1981: 37). Son las últimas palabras de la primera parte de la novela, una sentencia en la que ambos personajes, el autor y su alter ego, se unen en uno solo para transmitirle al lector el pesimismo de sus sensaciones compartidas. Sensaciones que acabarán conformando y confirmando el pesimismo de Orwell ante el futuro que se avecina: «se acabó esta tontería de volver al pasado. ¿De qué sirve empeñarse en visitar los lugares de la infancia, si éstos ya no existen? ¡Subir a por aire! Si no hay aire» (Orwell, 1981: 219).

Sin embargo, a pesar de esa evidente analogía entre el autor y su personaje, hay un elemento que los distingue a ambos: mientras que Bowling es más bien un pusilánime conformista, Orwell se siente a sí mismo como un socialista revolucionario capaz de concienciar al mundo de la necesidad de instaurar una nueva era ideológica en contra de las posturas totalitarias que parecían cobrar cada vez más fuerza. Christine Berberich define la diferencia entre ambos con las siguientes palabras:

Bowling en realidad es demasiado nostálgico, demasiado torpe, demasiado ajeno al mundo real como para representar al verdadero Orwell. Orwell sentía nostalgia por el pasado, sí. Pero también, más que nada, reclamaba un cambio social. Quería que las gentes de Inglaterra se despertasen y asumiesen responsabilidades políticas, quería una reorganización del sistema político y de clases y acabar con las viejas jerarquías. Pero no lo quería a cualquier precio; Orwell pretendía mantener ciertas formas, ciertos valores que habían resultado valiosos en el pasado y que podían aplicarse también al presente.

(Berberich, 2001: 51)

Añade Berberich que, en cierto sentido, Subir a por aire «parece no solo reflejar la nostalgia de Orwell por la vieja Inglaterra, sino también todas sus dudas sobre la nueva» (2001: 45), para después apuntar que precisamente toda esa desconfianza y esa antipatía por el mundo moderno puede ya ser advertida en las primeras páginas de la novela. Subir 
a por aire es el reflejo de la lucha entre la naturaleza y la ciudad, con un claro posicionamiento a favor de la primera y en contra de la segunda, es decir, en contra del exceso de industrialización, algo que desde luego está ligado al recurso a la infancia, pues precisamente esa crítica se produce debido al choque de realidades que han tenido que sufrir los habitantes de Inglaterra que crecieron alejados de las grandes ciudades y que ahora, en cambio, ya no pueden escapar de ellas. Años más tarde, en un artículo titulado Lugares de placer, Orwell, en uno de sus muchos arrebatos literarios, señalaría que «esa idea de admirar la naturaleza, de sentir una especie de reverencia religiosa al contemplar glaciares, desiertos o cascadas, está ligada al sentimiento de pequeñez y debilidad del hombre frente al poder del universo» (2013: 689). Esta imagen remite de forma evidente a la idea acerca de la experiencia de lo sublime recuperada por su compatriota Edmund Burke - así como por el filósofo Immanuel Kant, que habla de ella en la tercera de sus críticas, la Crítica del juicio-, según la cual la contemplación de ciertos elementos provoca en el espectador una sensación de embriaguez difícilmente asimilable, ante la cual se siente empequeñecido, incluso atemorizado. Se trata de una idea que adquirió una gran notoriedad durante el Romanticismo, y que se relacionó especialmente, no solo con la contemplación de la naturaleza, sino con la sensación de desborde que invadía a los seres humanos al contemplar esa naturaleza que nos sobrepasa.

Con el regreso de Bowling a su pueblo natal y la constatación de la desaparición de $s u$ Lower Binfield, lo que Orwell en realidad nos está mostrando es la desaparición de aquella Inglaterra idílica que era capaz de mirar al futuro, no con temor, sino con esperanza. «No se trata de la simple pérdida de una Inglaterra pacífica, agradable y rural, sino de un sentido de estabilidad» (Lewis, 1984: 159). Como señala José Luis Rodríguez (1983), lo que ha ocurrido en la nueva Inglaterra es que el progreso ha ocultado a la vieja y ha inventado una ciudad que se ha edificado justo encima del Lower Binfield de George Bowling. La tarea, por tanto, del humanismo orwelliano, consiste en «hacer emerger la auténtica naturaleza moral sorprendida en su buena fe por el imperio de la máquina» (Rodríguez, 1983: 66), o lo que es lo mismo, advertirnos de la existencia de una especie de vinculación entre los términos de «maldad» e «industria», que han enterrado la tradición y los valores del pasado. Pero el objetivo de dicho humanismo no es el de alcanzar una sociedad perfecta — el Golden Country es, recordemos, inalcanzable- , sino una sociedad mejor (Quintana Rubio, 2018). El viaje a Lower Binfield acaba, así, convirtiéndose en un viaje hacia el desengaño más absoluto, en un viaje hacia el desencanto, en un viaje hacia una realidad capaz de decirle a un tipo como George Bowling que él, igual que toda la clase media a la que pertenece, no podrá nunca llegar a ser feliz, porque las nuevas condiciones del mundo moderno jamás lo permitirán. Tanto Subir a por aire como Mil novecientos ochenta y cuatro suponen, en el fondo, una suerte de advertencia sobre los peligros a los que nos estamos dirigiendo. Los peligros de la infelicidad y del fracaso personal, que constituirán la realidad, de cuya huida es imposible, de todas aquellas personas que no pertenezcan a la clase dominante. Oriol Quintana (2016) resume eficazmente toda esa retahíla de sensaciones que la lectura de ambas novelas termina dejando en el lector al mencionar que en ellas se refleja lo absurdo que puede llegar a ser el concepto de felicidad en una sociedad que, en muchas ocasiones, coloca dicho término fuera de nuestro alcance; por ejemplo, en una infancia irrecuperable o en una civilización ya perdida. De hecho, esa felicidad perdida no solo es irrecuperable, sino que llega un momento en el que incluso se duda de su existencia. La vieja Inglaterra orwelliana se ha ido para dar paso a una Inglaterra industrial cargada de humo e inventos mecánicos. La naturaleza ha sido sustituida por la industria, y los espacios de libertad individual han comenzado a perder su razón de ser. 
Dice Frederick R. Karl (1968: 228) en su ensayo sobre la novela inglesa contemporánea que Mil novecientos ochenta y cuatro es algo así como un intento de Orwell por advertirnos, casi a modo de propaganda política, de lo que el totalitarismo puede llegar a provocar en Occidente si el socialismo no logra imponerse, peligros entre los cuales se encuentra la total aniquilación de ese estilo de vida que recuerda a la infancia de George Bowling en Lower Binfield. En Mil novecientos ochenta y cuatro la visión de la infancia aparece mucho más distante que en Subir a por aire. En ambas novelas, la referencia a la infancia se establece a través de momentos concretos, de pequeños objetos o de sensaciones, como si de aquellos recuerdos solo pudiesen ser rescatadas algunas situaciones que de ningún modo componen la totalidad de esa infancia, aunque son suficientes para reflejar esa nostalgia orwelliana por la vida inglesa previa a la llegada de la catástrofe. Pero mientras Bowling recuerda con enorme exactitud muchos de los fragmentos que componen sus vivencias infantiles, Winston Smith tan solo es capaz de recordarlas a modo de sutiles fogonazos, tan efímeros que no le queda más que dudar de su autenticidad. Así, la infancia de éste se materializa en un pisapapeles, en el olor del café, en una cancioncilla popular. Todos son elementos que, de una forma u otra, están ya destruidos o en proceso de destrucción en la sociedad que describe la novela. El pisapapeles es arrojado al suelo y se rompe en mil pedazos en el momento en que Winston es detenido; el olor del café que él bebe no tiene nada que ver con el que se bebía antaño; y la cancioncilla popular tiene una letra que Winston no alcanza a recordar. El pasado está a merced del poder, y quien controla el pasado lo controla todo. Como apunta Miquel Berga, en la sociedad descrita en Mil novecientos ochenta y cuatro «la destrucción del pasado y, por tanto, la imposibilidad de una realidad objetiva son indispensables para asegurar la perdurabilidad del sistema» (Berga, 1984: 27-28), lo cual se traduce en que nadie es libre de pensar ni de recordar nada más aparte de lo que aquellos que ostentan el poder deseen que pienses o recuerdes. Esa imposición, que es sinónimo de la ausencia de pensamiento libre, es lo que más teme Orwell. La posibilidad de dicha imposición es lo que aviva el pesimismo orwelliano, y también su desencanto, ambos inevitables una vez la guerra ya es una realidad.

\section{EL PESIMISMO, EL PATRIOTISMO Y LA LLEGADA DE LA GUERRA}

Uno de los grandes rasgos de Subir a por aire es el continuo y constante temor a la llegada de la guerra. A través de los ojos de Bowling, Orwell describe una sociedad que sabe que el conflicto bélico es inevitable. Ya desde el mismo comienzo de la novela la desolación es evidente: en un momento dado, tras ver sobrevolar un bombardero en pruebas por encima de su cabeza, Bowling apunta: «Dentro de dos años, dentro de un año, ¿qué haremos cuando veamos uno de esos trastos? Correr al sótano muertos de miedo...» (Orwell, 1981: 24). Cuando Bowling mira la ciudad que le rodea, esa mirada está cargada de nostalgia, pero es una nostalgia que no se dirige tan solo hacia el pasado, sino que también lo hace hacia el presente, hacia lo que ahora es y en poco tiempo ya no será. Es más, lo que parece es que Bowling, al ver cada rincón de su barrio, lo viese ya inevitablemente destruido:

Una mañana cualquiera, mientras la gente que va a trabajar invade como una gran corriente el puente de Londres, mientras canta el canario y la anciana tiende unos pantaloncitos en la cuerda, izuum, uiiizz, plonk...!, las casas saltarán por los aires, los pantaloncitos se mancharán de sangre, el canario cantará sobre los cadáveres.

(Orwell, 1981: 28)

En las descripciones hay, como vemos, un aire nostálgico hacia el presente: hacia lo que pronto dejará de ser. Es el mismo tipo de descripción que el propio Orwell hiciese 
apenas un año atrás, tras escribir, bajo el título de Homenaje a Cataluña (2010), la crónica de sus vivencias durante la Guerra Civil Española, hechos que, como apunta Miquel Berga, dominarán todos sus escritos a partir de ese momento: «la experiencia de la Guerra Civil cristaliza de tal manera en la personalidad del escritor que [...] significa un vuelco decisivo en su obra posterior» (Berga, 1984: 74). Tras regresar a casa, esto es lo primero que piensa Orwell:

Ahí estaba todavía la Inglaterra que había conocido en la infancia, con las flores silvestres ahogando los pasos del ferrocarril, los hondos prados donde pastan y meditan los lustrosos caballos, los lentos arroyos bordeados de sauces, las verdes copas de los olmos [...], todo, todo sumido en el profundísimo sueño de Inglaterra, del que a veces creo que no despertaremos hasta que nos sobresalten las explosiones de las bombas.

(Orwell, 2010: 205)

De su experiencia española nacen las bases que constituirán el Estado en el que habita Winston Smith, y también será dicha experiencia la que contribuya a orientar a Orwell hacia un pesimismo del que no se recuperará nunca. Por eso, si pudiésemos establecer diferentes fases dentro del pensamiento político de George Orwell, diríamos que la primera de esas fases, que podríamos denominar idealista, finaliza con la caída en el desencanto. Desencanto por una simple razón: porque el Orwell que acude a luchar a España es un Orwell revolucionario en su más romántico sentido, alguien ideológicamente impoluto que cree en la lucha armada como si ésta fuese la más noble de las acciones para combatir la llegada del terror. Es un Orwell que advierte la necesidad de luchar contra el fascismo, y que ve en la República Española, a su llegada a Barcelona, el más claro ejemplo de sociedad sin clases. En estos momentos, Orwell cree que España es el lugar apropiado para impedir la expansión del fascismo por el resto de Europa, pero su experiencia tanto en Barcelona como en el frente de batalla en Aragón le hacen advertir que la realidad es mucho más compleja de lo que podría llegar a parecer. De que el socialismo, llevado al extremo, puede convertirse también en un tipo de fascismo. De que el comunismo estalinista y el fascismo comparten, ambos, una tendencia totalitaria que puede llegar a ser catastrófica.

La manipulación de los medios y las continuas luchas entre grupos que, supuestamente, pertenecían todos ellos a la izquierda, hacen que se produzca en la mentalidad de Orwell un cierto desencanto que activó una especie de bomba en su pensamiento. La vivencia de la guerra española es un anticipo de lo que ocurrirá en Europa; la victoria del fascismo es, después de la llegada de Franco al poder, un temor ya concebible, ya pensable, ya imaginable. Y, sin embargo, Europa, y en especial Inglaterra, permanece dormida. Como si España no fuese más que un apéndice inconexo, en vez de un prólogo. Eso es lo que provoca el desencanto de Orwell: la apariencia de tranquilidad. Christine Berberich lo explica con las siguientes palabras: «incluso aunque él adore esa "tranquilidad" de la vida en el campo, es precisamente esa "somnolencia" del pueblo lo que él duramente critica» (Berberich, 2001: 38) ${ }^{7}$. En una carta enviada a A.S. Moos en noviembre de 1943, Orwell vuelve a avisar de lo que puede llegar a ocurrir en un futuro no muy lejano:

[...] que corremos el riesgo de que aparezca un Estado esclavista centralizado, gobernado por un pequeño grupo que será en efecto una nueva clase gobernante, aunque tal vez adoptiva en lugar de hereditaria. Dicho Estado no será hedonista ${ }^{8}$, al contrario, su dinamismo procederá de una especie de nacionalismo rabioso y un liderazgo mantenido

\footnotetext{
${ }^{7}$ La palabra inglesa sleepiness puede ser traducida a la vez como tranquilidad y somnolencia; en su versión original, la autora juega con este doble sentido.

${ }^{8}$ Muy probablemente, referencia a la sociedad de Un mundo feliz, obra de Aldous Huxley que Orwell conocía en profundidad. Huxley fue, de hecho, profesor de Orwell.
} 
por una guerra literalmente continua, y su nivel de vida medio probablemente será bajo. No espero volver a ver un desempleo masivo, salvo por desajustes temporales; creo que tal vez nos enfrentamos al peligro mucho mayor de los trabajos forzados y la esclavitud.

(Orwell, 2014: 201)

Entre Subir a por aire y Mil novecientos ochenta y cuatro pasan nueve años y una guerra, y de este período hay dos artículos especialmente relevantes para el tema que nos ocupa: El león y el unicornio, escrito en 1941, y Algunas reflexiones en torno al sapo común, escrito en 1946. En el primero de ellos, Orwell habla del auge del patriotismo en una época en la que los pueblos de Europa se juegan su futuro. El patriotismo es, de hecho, el nombre que podríamos otorgarle a la tercera de las fases del pensamiento orwelliano - la segunda sería una especie de confuso pacifismo que impregna algunos de los escritos del autor entre 1937 y 1939, y que el propio Orwell acaba desechando tras la firma del pacto entre Hitler y Stalin ${ }^{9}$ - , un patriotismo a través del cual se defiende la idea de que solo mediante la guerra es posible acabar con los totalitarismos que nos acechan. De ver la guerra como algo noble se pasa a la visión de la guerra como algo necesario. Esta es, sin embargo, la etapa más pesimista de Orwell, y ya desde la primera línea del mencionado ensayo de 1941 se introduce al lector en esa aura pesimista que envolverá todo el escrito: «Según escribo estas líneas, seres humanos sumamente civilizados me sobrevuelan intentando matarme» (Orwell, 2013: 271). Una de las ideas que más destaca en este ensayo, y que en cierto modo se ampliará años más tarde en el texto titulado $E l$ pueblo inglés, es la defensa de los valores ingleses más clásicos, especialmente del amor por la naturaleza ${ }^{10}$, de la libertad individual y de la privacidad más absoluta, aunque en el mundo moderno todas estas cosas se han ido perdiendo cada vez más. «Es evidente, por supuesto, que también esta libertad privada es una causa perdida» (Orwell, 2013: 275), escribirá. Mil novecientos ochenta y cuatro refleja este temor llevado al extremo, y el Golden Country ejemplifica esa pérdida. Piers Stephens va un paso más allá al señalar que el Golden Country no solo ejemplifica la pérdida de ese espacio de libertad, sino también la pérdida de las tradiciones políticas inglesas, que se ven amenazadas por «el lado oscuro de la modernidad» (Stephens, 2004: 85).

El otro de los ensayos que hemos mencionado, Algunas reflexiones en torno al sapo común, por estar escrito ya una vez finalizada la guerra, adquiere un tono todavía más nostálgico. En las apenas cuatro páginas que ocupa podemos entrever a un Orwell cuyo pesimismo es ya prácticamente absoluto. Un Orwell que cree que la posibilidad de que los sistemas totalitarios se nos acaben imponiendo en un futuro no muy lejano es algo que va más allá de la ficción, algo que es real. Es el Orwell de sus dos últimas novelas, el de Animal Farm y el de Mil novecientos ochenta y cuatro, pero, en cierto sentido, es también el Orwell de Subir a por aire, que nos habla de nuevo de la vuelta a la naturaleza como modo de escapar de la opresión de la era de las máquinas. En su ensayo sobre el sapo común, el George Orwell que habla es una especie de George Bowling que vuelve a ver necesario, como única forma de salvación individual, regresar a Lower Binfield en busca de un aire que, en realidad, ya no se puede respirar. Solo en esa vuelta a aquellas cosas que nos hicieron libres podemos, al final, recobrar la esperanza en este mundo.

Creo que conservando el amor de la infancia por cosas como los árboles, los peces, las mariposas y los sapos, hacemos que un futuro pacífico y decente sea un poco más probable, y que predicando la doctrina de que no hay que admirar nada salvo el acero y el hormigón, solo conseguiremos garantizar un poco más que a los seres humanos no les

\footnotetext{
${ }^{9}$ Un pacto que, en palabras de Peter Lewis, «aclaró maravillosamente su mente, expulsando su asqueado pacifismo como la niebla» (Lewis, 1984: 163).

${ }^{10}$ En este caso, Orwell habla en concreto de las flores. Suponemos que alguien de su procedencia no podía ser ajeno en absoluto a la influencia de los tradicionales jardines ingleses.
} 
quede otra válvula de escape para su excedente de energía excepto el odio y el culto a un líder.

(Orwell, 2013: 749)

Pero no se trata más que de un último grito desesperado, de un último intento por hacernos ver la realidad. Esa esperanza, sin embargo, parece ya perdida del todo en $\mathrm{Mil}$ novecientos ochenta y cuatro, una vez que la naturaleza ha sido vencida por la industrialización y una vez que los sistemas totalitarios han comenzado a instalarse en la sociedad europea, arrebatándonos parte de nuestros derechos y muchas de nuestras libertades. El Londres de su última novela es, ante todo, una advertencia basada en su experiencia personal. Allí ya no hay árboles, ni peces, ni siquiera infancia. Solo máquinas, hormigón, acero, odio y un líder que lo domina todo. Por eso el Golden Country es un lugar ideal: porque su inexistencia es absoluta.

\section{A MODO DE CONCLUSIÓN: EL GOLDEN COUNTRY COMO COROLARIO DEL PESIMISMO POLÍTICO ORWELLIANO}

A lo largo de estas páginas se ha intentado hacer un recorrido por parte de la obra de George Orwell, señalando más o menos cronológicamente aquellos elementos que acabarán configurando esa especie de huida hacia lo desconocido que supone el Golden Country. Desde el idealismo inicial del que parten sus primeros escritos hasta el patriotismo final en el que la guerra se ve como única opción para acabar con los totalitarismos; desde su cruzada personal contra la imposición del mecanicismo sobre la naturaleza, junto con todos los valores que esta representa, hasta el pesimismo casi existencial de su última novela, cuando todo parece ya perdido. Ese recorrido nos ha ido mostrando todos aquellos elementos que, al final, acabarán formando parte del concepto en el que nos hemos centrado. En este sentido, podríamos decir que el Golden Country ejemplifica los anhelos más profundos de su autor, pero también encierra una crítica a la sociedad de la época, una crítica realizada a modo de advertencia acerca de la potencialidad real de acabar perdiendo nuestros espacios de libertad y privacidad, nuestra propia intimidad. El Golden Country representa, en definitiva, todo aquello que podemos llegar a perder si las tendencias totalitarias acaban imponiéndose en nuestra sociedad.

Orwell, igual que ya hiciese Huxley en Un mundo feliz - aunque este con otro enfoque diferente, orientado especialmente al ocio y al placer-, es uno de los primeros autores en advertirnos sobre el problema y el auge del totalitarismo, concepto especialmente relevante dentro de la filosofía política del siglo veinte. Así, autores como Hannah Arendt, Elias Canetti o Michel Foucault, entre otros, se encargarán de analizar y profundizar en los nuevos modelos de instauración del poder. Especialmente relevante para la teoría política son los escritos de Arendt, que habla, entre otras cosas, de aquellas formas de gobernanza en las que la violencia domina de forma absoluta, tal y como sucede en los regímenes totalitarios, en los que «no solo se callan las leyes, sino que todo y todos deben guardar silencio» (Arendt, 1988: 19). Precisamente la falta de silencio es, entre otras cosas, lo que condena a Winston Smith. El atreverse a hablar. Porque mantener en silencio a la gente es, por supuesto, una de las múltiples formas que tiene el Estado totalitario de ejercer su violencia, pero no la única. Lo más peligroso de este tipo de violencia, además, es que puede acabar desembocando en aquello que Orwell más temía: el temor a que el poder domine y reprima la verdad, llegando incluso a alterar la historia según su conveniencia, o incluso a borrarla. Algo que Orwell consideraba propio de los regímenes totalitarios, a pesar de que la historia nos haya enseñado que no es necesario vivir en un régimen totalitario para ser testigos de los usos y los abusos totalmente 
partidarios que pueden llegar a hacerse de la historia (Mohomed, 2011). En el caso de Mil novecientos ochenta y cuatro, el propio Winston trabaja modificando las noticias de los periódicos. Aunque sea un régimen cuyo gobierno se presenta ante los ciudadanos como absolutamente racional, en realidad esta racionalidad se debe a que él mismo se la ha otorgado, puesto que posee la capacidad - y los medios- para ello.

Ante la inminente llegada del totalitarismo lo único que nos queda es, por tanto, el pesimismo. Pesimismo porque del totalitarismo nunca podemos escapar, aunque lo intentemos. Winston Smith refleja el intento de escapada de ese régimen, pero también su fracaso. Así, la relevancia del concepto de Golden Country para el conjunto total de la obra de Orwell se muestra como algo esencial: tras él se encierran los anhelos más profundos de su autor, pero, sobre todo, se encierra también una crítica feroz a la sociedad moderna, crítica que es formulada a partir de la creación de un espacio imaginario que nos advierte de todos aquellos valores que el ser humano puede llegar a perder si se rinde a las tentaciones totalitarias que Orwell, como pocos, supo detectar y denunciar en los movimientos políticos de su tiempo.

\section{REFERENCIAS BIBLIOGRÁFICAS}

Arendt, Hannah (1988). Sobre la revolución. Trad. Pedro Bravo. Madrid: Alianza Editorial.

Barrell, John. 1992. «Sportive Labour: the farmworker in eighteenth-century poetry and painting». En The English rural community: image and analysys, ed. Brian Short. Cambridge: Cambridge University Press, pp. 105-132.

Benjamin, Walter. 1982. Infancia en Berlín hacia 1900. Trad. Klaus Wagner. Madrid: Alfaguara

Berberich, Christine. 2001. «A revolutionary in love with the 1900s: Orwell in defence of "Old England"». En The road from George Orwell: his achievement and legacy, ed. Alberto Lázaro. Bern: Peter Lang, 33-52.

Berga, Miquel. 1984. Mil nou-cents vuitanta-quatre: radiografia d'un malson. Barcelona: Edicions 62.

Bloom, Harold. 2004. Bloom's Guide: George Orwell's 1984. Nueva York: Chelsea House.

Brunsdale, Mitzi M. 2000. Student companion to George Orwell. Londres: Greenwood Press.

Bowker, Gordon. 2003. George Orwell. Londres: Little, Brown.

Coppard, Audrey y Bernard Crick, comp. 1989. Memoria y evocación de George Orwell. Trad. José Andrés Pérez Carballo. México: Fondo de Cultura Económica.

Crick, Bernard. 1992. George Orwell. A life. Inglaterra: Penguin Books.

Cushman, Thomas. 2004. «Introduction». En George Orwell into the Twenty-first Century, eds. Thomas Cushman y John Rodden. Londres: Paradigm Publishers, pp. $1-20$.

Fowler, Roger. 1995. The Language of George Orwell. Londres: MacMillan Press.

Karl, Frederick R. 1968. La novela inglesa contemporánea. Trad. Rosario Berdagué. Barcelona: Lumen.

Lewis, Peter. 1984. George Orwell. El camino a 1984. Trad. Joaquín Bochaca. Badalona: El laberinto.

Manuel, Frank E. y Fritzie P. Manuel. 1984. El pensamiento utópico en el mundo occidental. Tomo III: La utopía revolucionaria y el crepúsculo de las utopías (siglo XIX-XX). Trad. Bernardo Moreno Carrillo. Madrid: Taurus. 
Marinelli, Peter. 2018. Pastoral. The Critical Idiom Reissued. Oxon y Nueva York: Routledge.

Mohomed, Carimo. 2011. «The abolition of the Past: History in George Orwell's 1984». 2nd International Conference on Humanities, Historical and Social Sciences. IPEDR, 17: 71-76

Orwell, George. 1981. Subir a por aire. Trad. Ester Donato. Barcelona: Destino.

—. 2002. 1984. Trad. Rafael Vázquez Zamora. Barcelona: Destino.

—. 2010. Orwell en España. Homenaje a Cataluña y otros escritos sobre la Guerra Civil Española. Trad. Antonio Prometeo Moya. Barcelona: Tusquets Fábula.

—. 2013. Ensayos. Trad. Miguel Martínez-Lage, Juan Antonio Montiel, Jordi Soler (ensayos seleccionados). Barcelona: Debate.

—. 2014. Escritor en guerra: correspondencia y diarios (1937 - 1943). Trad. Miguel Temprano García. Barcelona: Debate.

Quintana, Oriol. 2016. Filosofía para una vida peor. Breviario del pesimismo filosófico del siglo XX. Madrid: Punto de Vista Editores.

—. 2018. «La condición del hombre corriente y el humanismo de George Orwell». Razón y Fe, 277 (1432): 185-194.

Rai, Alok. 1990. Orwell and the politics of despair. A critical study of the writings of George Orwell. Cambridge: Cambridge University Press.

Rodríguez, José Luis. 1983. «Lo social y lo natural en el humanismo orwelliano». Miscelánea: A Journal of English and American Studies, 4: 59-70.

Shin, Kunio. 2017. «The Uncanny Golden Country: Late-Modernist Utopia in Nineteen Eighty-Four». Modernism/modernity, 2 (2). doi: https://doi.org/10.26597/mod.0007

Stephens, Piers. 2004. «Nature and human liberty: The Golden Country in George Orwell's 1984 and an alternative conception of human freedom». Organization \& Environment, 17 (1): 76-98. doi: https://doi.org/10.1177/1086026603262032

Trousson, Raymond. 1995. Historia de la literatura utópica. Viajes a países inexistentes. Trad. Carlos Manzano. Barcelona: Península.

Woodcock, George. 1966. The crystal spirit. A study of George Orwell. Boston-Toronto: Little, Brown and Company. 